\title{
A ADESÃO DE PORTUGAL ÀS COMUNIDADES EUROPEIAS E AS RELAÇÕES COMERCIAIS COM OS PAÍSES TERCEIROS
}

\author{
Luís Pedro Cunha
}

\section{PORTUGAL FACE AO EXTERIOR, 1948-1986}

\subsection{Evolução da Política Comercial}

Podemos encarar a política comercial portuguesa de 1948 a 1986 como tendo sido, institucionalmente, a face vísivel de um longo processo de internacionalização da nossa economia (neste sentido, SILVA, 1989: 87). Mesmo que tal processo de internacionalização se tenha, por fim, revelado funcionalmente como processo de transição para a entrada nas Comunidades Europeias (CEE) (MACEDO e outros, 1988: 29).

No pós-guerra (fins dos anos 40 e década de 50) Portugal aderiu a duas organizações internacionais que procuraram facilitar o comércio externo; a Organização Europeia de Cooperação Económica (OECE), instituição de liberalização do comércio, e a União Europeia de Pagamentos, que procurava liberalizar os pagamentos internacionais. Com especial relevo, iniciou-se o abandono das restrições quantitativas e de outros controlos de trocas com o exterior (v.g. licenças e contingentes). Esse procedimento, conforme com as nossas obrigações no quadro da OECE, processou-se relativamente depressa: em 1954, na OECE, a percentagem de sectores não afectados pelas restrições quantitativas cifrava-se em $73 \%$, e em Portugal atingia o valor de $93 \%$.

A tributação alfandegária representava então o instrumento principal de intervenção comercial. Neste período de tempo, a média (protecção nominal) dos impostos alfandegários tende a aumentar; em 1948 era de 9,9\% e em 1959 atingia os $14,2 \%$. Protegiam-se fundamentalmente indústrias nascentes e indústrias orientadas para a substituição de importações ${ }^{1}$.

Nos anos 50 procurou-se promover a integração económica entre a metrópole e os territórios ultramarinos portugueses, pois tornava-se imperativo fazer acompanhar a realidade política de adequadas ligações económicas, neste particular de mais intensos fluxos comerciais (para uma visão mais crítica do comércio ultramarino, ver ÁLVARES e FERNANDES, 1980:14-15). Aprovou--se então 
um conjunto de reduções alfandegárias, especialmente vantajoso para os territórios ultramarinos ${ }^{2}$.

A década de 60 fica marcada, em termos de política comercial, pela substituição da Pauta Alfandegária de 1929 (1959) pela adesão de Portugal à Associação Europeia de Comércio Livre (EFTA), em 1960, e pelas adesões à estrutura institucional do GATT (Acordo Geral sobre Impostos Alfandegários e Comércio), ao FMI (Fundo Monetário Internacional) e ao BIRD (Banco Internacional de Reconstrução e Desenvolvimento, ou Banco Mundial), nos anos seguintes. Pelo facto de ter aderido ao GATT, Portugal fez vigorar no país as reduções alfandegárias acordadas no Kennedy Round (1964-67).

A entrada de Portugal na EFTA representou a opção nacional possível face à «bipolarização» comercial da Europa, que ameaçava discriminar negativamente as exportações portuguesas. A opção pela EFTA, face a uma hipotética opção pelas Comunidades, representava a escolha por um movimento com um menor grau de integração (zona de comércio livre para produtos industriais $v s$. união aduaneira), ao mesmo tempo que permitia acompanhar-se o Reino Unido, mercado tradicional de exportação ( $12 \%$ das exportações da época). Evitava-se assim a perda de autonomia política e económica, nomeadamente no que respeitava às relações com os territórios ultramarinos e à continuação de uma política de substituição de importações, ao mesmo tempo que se beneficiava da pertença a um «grupo» de impacto regional, com poder negocial face às Comunidades. Será conveniente lembrar que, por ocasião da criação das Comunidades, já as mesmas representavam cerca de 1/4 das exportações portuguesas.

No conjunto dos países membros da EFTA, Portugal era o menos desenvolvido. Conseguiu assim negociar um esquema de liberalização das importações específico (Anexo $\mathrm{G}$ da Convenção de Estocolmo), não tendo que conferir vantagens simultâneas equiparadas aos outros participantes. Assim, enquanto que $87 \%$ das exportações portuguesas puderam desde logo beneficiar do regime da Convenção, só $23 \%$ das importações ficaram sujeitas ao mesmo regime, ficando $65 \%$ sujeitas ao regime, mais proteccionista, do Anexo $\mathrm{G}^{3}$.

Tendo em conta todos os compromissos internacionais subscritos por Portugal na década de 60 , não é de estranhar que se tenham afastado as restrições cambiais, a generalidade das restrições quantitativas, e que se tenham verificado reduções nos impostos nominais. A média desses impostos, que se cifraria em $18,2 \%$ em 1964, ver-se-ia reduzida para 14,4 em 1970 (PORTO, 1986a). No entanto, e segundo o mesmo autor, no mesmo período de tempo, a protecção efectiva aumentou de uma média de $48,4 \%$ para uma média de $50,7 \%$, favorecendo os sectores de indústrias nascentes, orientados para a substituição de importações, mais capital-intensivos ou que criassem mais emprego, e prejudicando aqueles sectores onde se apurasse um coeficiente significativo e negativo de correlação entre as taxas nominais e os valores da elasticidade-preço da procura de importações. Ficavam bem demonstrados os propósitos reditícios já assinalados. Temos assim que, para uma queda percentual de $21 \%$ nos valores 
nominais, nos confrontamos com uma subida percentual de $5 \%$ nos valores efectivos.

A década de 70 pode ser considerada como tendo representado um avanço livre-cambista, mais visível no que respeita à protecção nominal. $O$ condicionamento industrial é abandonado e a protecção às indústrias orientadas para a substituição de importações é posta de lado, apostando-se mais nas indústrias nascentes e nas indústrias orientadas para as exportações. Contudo, no decurso desta década, temos que contar com a importante excepção do período de 1974-76, onde razões conjunturais, de ordem económica, conduziram as autoridades governamentais à adopção de fortes barreiras não alfandegárias, de forma a restringir o volume do comércio externo (importações), sem que para tal se violassem abertamente acordos anteriormente assumidos.

Em 1972 Portugal celebra um Acordo de Comércio Livre com a CEE (produtos industriais). A necessidade desse acordo já se faria sentir anteriormente a 1972, pois a interdependência entre Portugal e a Europa tinha aumentado, provocada pela deslocação do factor trabalho, pelo aumento espectacular das exportações de manufacturas, pela maior abertura ao turismo e ao investimento directo. As Comunidades, em especial, posicionavam-se como um dos principais parceiros de Portugal, adquirindo um peso reforçado a partir do momento em que o Reino Unido delas passou a fazer parte. No âmbito desse Acordo com as Comunidades, estabeleceram-se calendários para efectivar reduções alfandegárias, sendo Portugal beneficiado com um plano de reduções mais demorado ${ }^{4}$.

Nesta primeira fase de avanço liberal e livre-cambista (1970-1974), nota-se também uma quebra acentuada da média dos valores nominais, de $14,4 \%$ para $7,7 \%$ ), acompanhada por uma quebra menos acentuada da média das taxas efectivas, de $50,7 \%$ para $31,5 \%(38,1 \%)$. A tendência de os valores efectivos assumirem uma crescente importância relativa é visível. Se confrontarmos os dados já apresentados, vemos que em 1964 a média da protecção efectiva era 2,65 vezes superior à média da protecção nominal, sendo, em 1974, 4,1 vezes superior (PORTO, 1982).

Em 1974, a orientação livre-cambista da nossa política comercial termina abruptamente. Nesse ano já se fazem sentir internamente com acuidade os efeitos da crise petrolífera e da recessão mundial, agravados por factores internos. De 1973 para 1974, o défice da balança comercial aumenta de menos de 18 milhões de contos para mais de 50 milhões de contos, enquanto que os saldos das transferências correntes e do turismo se mantêm sensivelmente ao mesmo nível de 1973, resultando daí um défice da balança de pagamentos correntes de cerca de 20 milhões de contos, o primeiro desde 1961 (ÁLVARES e FERNANDES, 1980: 16) ${ }^{5}$.Em 1975 o défice da balança comercial diminuiu, embora o valor das exportações tenha baixado devido à perda dos mercados ultramarinos e à queda da procura estrangeira (para aumentar de novo em 1976 e 1977). Isto porque a contracção nas importações foi ainda maior, em virtude do abrandamento da acti- 
vidade económica, com reflexos no investimento e na produção industrial, e das políticas restritivas adoptadas ${ }^{6}$.

No decurso desta década a pauta aduaneira vai perdendo relevo, pois a sua natureza fundamentalmente específica não lhe permite acompanhar o aumento dos preços dos bens importados 7 .

Em Junho de 1976 é celebrado um Protocolo adicional ao Acordo com a CEE de 1972, onde, entre outros objectivos, se conseguiu adiar o desarmamento alfandegário previsto, acrescendo assim a protecção auferida pelas indústrias portuguesas (nascentes ou não), face aos seus concorrentes comunitários. Curiosamente, o pedido de adesão às Comunidades, por parte de Portugal, verifica-se logo em Março de 1977. Razões políticas teriam sido determinantes na tomada desta decisão.

Em 1979 assinava-se um Acordo entre as Comunidades, a EFTA e a Espanha. Pela via da nossa participação na EFTA e como resultado desse Acordo, eram, pela primeira vez no período considerado neste trabalho, reduzidas as barreiras alfandegarias entre os dois países ibéricos ${ }^{8}$.

Os anos finais da década de 70 são assinalados por algum avanço livre-cambista, tendo como referência o período 1974-76. Em 1980 os impostos nominais e as sobretaxas tinham descido, nomeadamente para os bens intermediários e de consumo.

De 1980 a 1983 assistimos a um retrocesso conjuntural. Por um lado, aumentam os contingentes e as licenças para a importação, de modo a tentar controlar o excesso de procura de moeda estrangeira. Não tendo sido as restrições quantitativas suficientes, procedeu-se em 1983 a uma nova desvalorização do escudo. Por outro lado, procede-se, de 1980 a 1982, à conversão da pauta alfandegária de específica em ad valorem. Essa conversão foi acompanhada, na generalidade dos casos, por um agravamento dos impostos. Aumentavam assim as receitas e a protecção ${ }^{9}$ e fortalecia-se a nossa posição negocial face à CEE, quanto à adopção progressiva e escalonada da Pauta Exterior Comum. Essa adopção viria a traduzir-se por uma quebra sensível dos valores da protecção nominal e da protecção efectiva, com discrepâncias importantes entre os níveis de protecção de sector para sector. Segundo os autores (PORTO, 1982 e 1986; MACEDO e outros, 1988), da comparação da Pauta portuguesa de Julho de 1981 e da PEC de 1982 pode-se concluir que a média da protecção nominal baixou de 14,4 para 10,6 e a média da protecção efectiva de 32,9 para 22,6 .

\subsection{Evolução do Comércio Externo}

Tentaremos agora analisar como evoluiu o comércio externo português nas últimas décadas, ou, por outras palavras, que tendências o determinaram. Será interessante perspectivar essa análise tendo em conta o facto de Portugal ter aderido às Comunidades. Nomeadamente será interessante saber se essa adesão correspondeu a um culminar de uma tendência de Portugal para privilegiar a Europa 
como o primeiro espaço comercial (à parte questões políticas), ou se, pelo contrário, o resto do mundo (e, nomeadamente, as ex-colónias) constituiu um importante pólo de atracção para as nossas correntes comerciais. Esta primeira questão prende-se com a evolução (e os efeitos) da distribuição geográfica do comércio externo. Trataremos também de analisar a evolução da composição das exportações e das importações portuguesas, de modo a se irem destacando os sectores com que a adesão forçosamente mais teria de implicar.

A nossa análise incidirá separadamente sobre dois períodos de tempo, de modo a serem destacados os efeitos da integração na EFTA e do Acordo com a CEE de 1972.

Começemos por observar os quadros I e II. Os quadros mostram-nos como foi variando a distribuição geográfica das importações e das exportações de Portugal entre 1954 e 1959, e entre 1959 e 1967. Serão comparáveis os efeitos da integração na EFTA e os resultados da política comercial ultramarina levada a cabo desde os anos 50 (referida supra).

\section{QUADRO I}

Distribuição das importações da Metrópole por Regiōes

(em \% c.i.f..)

\begin{tabular}{|c|c|c|c|c|c|c|c|c|c|c|c|c|c|}
\hline Regiỗes & $\underset{\mathbf{s}}{\mathbb{S}}$ & 岂 & 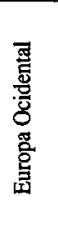 & 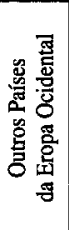 & 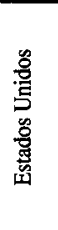 & 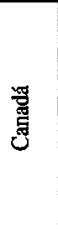 & 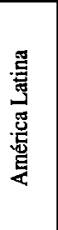 & 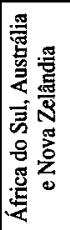 & 愛 & 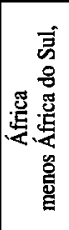 & 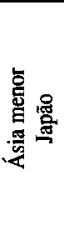 & 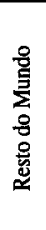 & 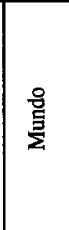 \\
\hline 1954 & 22.7 & 34.0 & 0.2 & 1.0 & 8.3 & 0.7 & 5.0 & 1.7 & 0.2 & 18.8 & 7.4 & - & 100.0 \\
\hline 1959 & 20.8 & 39.0 & 1.0 & 1.9 & 6.1 & 0.5 & 4.5 & 1.6 & - & 16.5 & 8.1 & - & 100.0 \\
\hline 1967 & 23.3 & 33.6 & 1.1 & 6.0 & 7.0 & 0.6 & 3.7 & 1.1 & 0.5 & 18.1 & 5.0 & - & 100.0 \\
\hline
\end{tabular}

FONTE: Xavier (1970: 53-54)

No primeiro dos períodos considerados regista-se um decréscimo das importações de Portugal com origem nos países que viriam a constituir a EFTA (menos $8,4 \%$ ), acompanhado por uma quebra ainda superior nas nossas exportações para esses países (menos 16,2\%). No que toca às Comunidades (dos «seis») a tendência verificada foi inversa, tanto no que respeita às importações como às exporta- 
ções (verificaram-se aumentos percentuais de $14,7 \%$ e de $19 \%$, respectivamente). Por outro lado, Portugal, tanto em 1954 como em 1959, importava mais dos países das Comunidades do que dos países futuros co-contratantes da EFTA (em 59 os valores eram de $39 \%$ contra $20,8 \%$ ). Também se exportava mais para o Mercado Comum de então (em 59 os valores eram de $22,7 \%$ contra $17,6 \%$; é sempre de realçar que o Reino Unido representava $12 \%$ das nossas exportações globais). Globalmente, entre 1954 e 1959, o mercado europeu manteve a primazia como nosso principal espaço comercial (em 1954 57,9\% das nossas importações são europeias (Ocidente) e 45,4\% das nossas exportações destinam-se à Europa Ocidental; em 1959 o valor percentual das importações eleva-se para 62,7\% e o das exportações mantem-se estável: $44,7 \%$ ). Convirá agora analisar o comportamento dos fluxos comerciais entre a metrópole e os territórios ultramarinos. Embora dos quadros I e II não constem dados suficientemente desagregados quanto às perfomances comerciais entre a metrópole e os territórios ultramarinos (estão incluídos nos valores da coluna "África menos África do Sul»), a ideia que se pode retirar é a de que as importações com origem em África, de onde avultam as importações com origem nos territórios ultramarinos, decresceram, não obstante os esforços produzidos nessa década para contrariar tal situação. Quanto às exportações da metrópole com destino a África, elas aumentaram no período considerado, demonstrando aparentemente maior sensibilidade às reduções alfandegárias então praticadas.

QUADRO II

Distribuição das exportações da Metrópole por Regiōes (em \% c.i.f..)

\begin{tabular}{|c|c|c|c|c|c|c|c|c|c|c|c|c|c|}
\hline Regiōes & 謧 & 푱 & 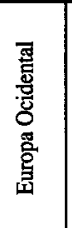 & 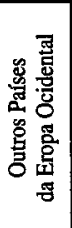 & 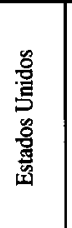 & $\begin{array}{l}\text { 罵 } \\
\text { 常 }\end{array}$ & 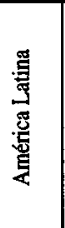 & 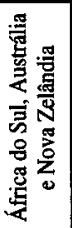 & 惫 & 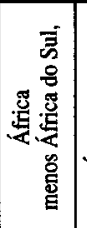 & 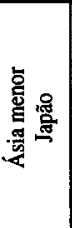 & 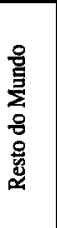 & $\frac{8}{\frac{0}{2}}$ \\
\hline 1954 & 21.0 & 19.0 & 2.4 & 3.0 & 10.4 & 0.8 & 4.9 & 2.2 & 0.4 & 32.0 & 2.8 & 1.1 & 100.0 \\
\hline 1959 & 17.6 & 22.7 & 2.1 & 2.3 & 9.8 & 1.0 & 3.4 & 1.4 & 0.6 & 34.1 & 4.6 & 0.4 & 100.0 \\
\hline 1967 & 32.9 & 16.9 & 1.1 & 3.2 & 10.2 & 1.6 & 2.4 & 1.3 & 0.9 & 26.6 & 2.4 & 0.5 & 100.0 \\
\hline
\end{tabular}

O segundo dos períodos (1959-1967) afirma algumas das tendências salientadas e contraria outras. No seu conjunto, a Europa Ocidental continua a ser o principal parceiro comercial de Portugal, com peso acrescido; as importações portuguesas com origem europeia aumentam $2 \%$ (de $62,7 \%$ para $64 \%$ ), ou seja, quase nada, embora se mantenham ao nível mais significativo; quanto às exportações 
portuguesas com destino europeu, passam de $44,7 \%$ das exportações globais para $54,1 \%$, isto é, sofrem um significativo aumento relativo de $21 \%$. É confirmada a vocação de relacionamento comercial primordial entre Portugal e os restantes países da Europa Ocidental. No entanto, no espaço infra-europeu verifica-se que as posições relativas das Comunidades e dos países da EFTA se invertem parcialmente. A EFTA assume-se agora como sendo o principal dos mercados europeus para a exportação portuguesa: em 1967 Portugal exporta para a EFTA $32,9 \%$ das suas exportações globais, contra 17,6\% em 1959. O aumento é fora do comum: $87 \%$. As Comunidades assumem um papel secundário, representando, em 1967, destino para $16,9 \%$ das exportações portuguesas, contra $22,7 \%$ em $1959^{10}$. No que respeita às importações de Portugal com origem europeia, as Comunidades mantiveram-se como os nossos principais fornecedores, logo seguidos pela EFTA. Contudo, a percentagem das importações com origem comunitária baixou $13,8 \%$ (de 39 para $33,6 \%$ ), tendo a percentagem das importações com origem na EFTA aumentado $12 \%$ (de $20,8 \%$ para $23,3 \%$ ). São visíveis os efeitos da integração de Portugal na EFTA. Também se confirma o insucesso da tentativa de integrar mais fortemente a metrópole e os territórios ultramarinos. A percentagem das exportações com destino a África diminuiu e, segundo MACEDO (e outros, 1988), também decresce a percentagem de importações com origem nos territórios ultramarinos (informação não confirmada pelos dados do quadro I que, no entanto, apresenta valores insuficientemente desagregados). Também, segundo os mesmos autores, a balança comercial da metrópole com os territórios ultramarinos se foi invertendo gradualmente de positiva para negativa, no decurso dos anos 60 .

A tendência para uma progressiva concentração do comércio externo português no espaço europeu revê-se, como não poderia deixar de ser, em algum esvanecimento no montante (relativo) dos fluxos comerciais com países e/ou zonas económicas que não os europeus. Assim, são visíveis, em ambos os quadros, quebras na importância relativa do comércio com os EUA (pelo menos confrontando os dados de 1954 e 1967), com a América Latina, com a África do Sul, Austrália e Nova Zelândia e com a Ásia (menos o Japão). Só os mercados japonês e canadiano se tornam relativamente mais importantes, o primeiro como destino e origem de mercadorias, o segundo como destino.

As conclusões que retirámos assentam em dados que se compatibilizam com outros. Vejamos em primeiro lugar aqueles apresentados por MACEDO (e outros, 1988), que se referem a um período um pouco mais longo, de 1954 a 1973. Este autor diz-nos que, no decurso do período considerado, as importações portuguesas com origem europeia, no cômputo global, mantiveram o mesmo peso relativo (entre $56,7 \%$ e $56,6 \%$ ), tendo sido acompanhadas por um aumento das nossas exportações, em termos relativos, de $40 \%$ para $62,4 \%$ (aumento de $56 \%$ ). As importações com origem colonial teriam decrescido $41 \%$ (de $17 \%$ para $10,1 \%$ ), e outro tanto teriam decrescido as exportações com destino colonial (de $25 \%$ para $14,8 \%$ ). $O$ resto do mundo (especialmente os EUA) veria a sua impor- 
tância acrescida como mercado de importação (as importações aumentariam $27 \%$ ), mas perderia peso como mercado de exportação (que diminuiriam $35 \%$ ). Passemos em seguida ao Quadro III que nos informa acerca da evolução das importações da CEE, da EFTA e dos Estados Unidos em proveniência de Portugal. Os dados fornecidos representam percentagens das respectivas importações em proveniência do mundo inteiro, de forma que traduzem não apenas a evolução das nossas exportações, mas também a evolução das exportações de todo o mundo, o que retirará alguma clareza à sua análise. De qualquer modo, as tendências referidas (período 59-72) confirmam-se; o mercado dos «seis» perde importância relativa na sequência da criação da EFTA, que adquire a supremacia. $\mathrm{O}$ mercado norte-americano parece adquirir também alguma importância acrescida como mercado de exportação, o que não contraria os dados de que dispomos no Quadro II, referentes ao período de 1959-1967.

\section{QUADRO III}

Importações da CEE, da EFTA e dos Estados Unidos

em proveniência de Portugal

(Em percentagem das respectivas importações em proveniência do mundo inteiro)

\begin{tabular}{|l|r|r|r|r|}
\hline Importadores & «Seis» & $\begin{array}{c}\text { Parses } \\
\text { Dinamarca } \\
\text { e } \\
\text { Reino Unido }\end{array}$ & $\begin{array}{c}\text { constituintes } \\
\text { da actual } \\
\text { FrTA } \\
\text { (excepto } \\
\text { Portugal) }\end{array}$ & $\begin{array}{c}\text { Estados } \\
\text { Unidos }\end{array}$ \\
\hline Grupos de mercadorias & & & & \\
Todas as mercadorias à excepção dos & & & & \\
combustíveis & 0,33 & 0,39 & 0,35 & 0,22 \\
1959 & 0,23 & 0,93 & 0,62 & 0,28 \\
1972 & 0,28 & 0,73 & 0,52 & 0,14 \\
1977 & & & & \\
& & & & \\
Têxteis & 0,02 & 0,27 & 0,92 & 0,76 \\
1959 & 0,38 & 4,92 & 3,22 & 1,38 \\
1972 & 0,52 & 4,67 & 2,36 & 0,85 \\
1977 & & & & \\
Vestuário & & & & \\
1959 & 0,00 & 0,00 & 0,17 & 0,79 \\
1972 & 0,24 & 7,59 & 5,61 & 0,48 \\
1977 & 0,79 & 3,41 & 3,72 & 0,18 \\
\hline
\end{tabular}

FONTE: Álvares e Fernandes, 1980: 37 
Analisemos os anos pós-1972. Com o auxílio do Quadro IV rapidamente nos apercebemos da evolução do nosso comércio com as Comunidades. Mas essa evolução foi função, entre outros, de dois factores, que convém destacar e dissociar: em primeiro lugar, o Acordo de Comércio Livre celebrado entre Portugal e as Comunidades; e, em segundo lugar, a transferência do Reino Unido e da Dinamarca da EFTA para a CEE (desde Janeiro de 1973). Vejamos então como evolui o nosso comércio, tendo sempre em conta esses dois factores. $\mathrm{O}$ aumento das nossas exportações com destino ao mercado comum foi muito significativo, passando de $20,9 \%$ das exportações totais em 1972 para 55,5\% em 1978. Simplesmente, tal aumento deve-se, em grande parte, à transferência acima referida. Devem-se portanto isolar os efeitos dessa transferência, se quisermos obter uma ideia mais realista acerca dos efeitos do Acordo de Comércio Livre. Tal isolamento pode ser obtido de dois modos; ou ficcionando a existência de uma CEE dos «nove» já em 1972, ou ficcionando a permanência de uma CEE dos «seis» em 1978. A primeira possibilidade tem, sobre a segunda, a vantagem de permitir apreciar não só os efeitos do Acordo sobre o comércio com os «seis», mas também os efeitos da alteração do regime comercial entre Portugal, por um lado, e o Reino Unido e a Dinamarca, pelo outro (o comércio com a Irlanda não apresenta valores minimamente significativos). Isto porque deixou de vigorar entre estes países a Convenção de Estocolmo para passar a vigorar o dito Acordo.

Portugal viu, entre 1972 e 1978, a percentagem das suas exportações com destino à CEE dos «nove» passar de $46,7 \%$ das exportações totais para $55,5 \%$. Registou-se um aumento de $18,8 \%$. Contudo, o efeito de expansão das exportações verificou-se, e em medida muito sensível, apenas no que respeita aos «seis» (mais 69,3\%), registando-se mesmo uma contracção nas exportações para os mercados britânico e dinamarquês (menos $22 \%$ ). O mesmo tipo de comportamentos se pode observar no que respeita à evolução das importações; se a CEE dos nove continuou, globalmente, a representar $45,8 \%$ das importações totais, esse facto resultou de um acréscimo de peso dos mercados dos «seis» (mais $11,1 \%$ ), que veio a compensar um decréscimo de peso dos mercados britânico e dinamarquês (menos 25,3\%). Partindo destes dados não será arriscado afirmar-se que o Acordo de Comércio Livre celebrado entre Portugal e as Comunidades produziu efeitos positivos e que a transferência do Reino Unido e da Dinamarca da EFTA para a CEE produziu efeitos negativos, no que respeita a fluxos comerciais ${ }^{11}$.

Vejamos agora dados acerca de outros países ou zonas económicas. A importância do comércio com a EFTA (dos cinco) diminuiu. Tal facto, pelo lado das exportações, poderá prender-se, como já referimos supra, com a existência de padrões de procura similares na EFTA e na CEE. Quanto aos EUA, as exportações que se the dirigiam diminuíram, face às exportações totais, cerca de $35 \%$. As importações aumentaram 32,5\%; uma possível explicação será o facto de os EUA serem, na época, um grande fornecedor de bens essenciais, menos sujeitos, por exemplo, às medidas restritivas dos anos de 1975 e 1976. Razões políticas, 
QUADRO IV

Distribuição geográfica do comércio externo

\begin{tabular}{|c|c|c|c|c|c|c|c|c|}
\hline \multirow{3}{*}{ Paises e zonas de origem e de destino } & \multicolumn{4}{|c|}{ Importaçסes } & \multicolumn{4}{|c|}{ Exportaçōes } \\
\hline & \multicolumn{2}{|c|}{1972} & \multicolumn{2}{|c|}{1978} & \multicolumn{2}{|c|}{1972} & \multicolumn{2}{|c|}{1978} \\
\hline & $\begin{array}{l}\text { Milhões } \\
\text { de } \\
\text { contos }\end{array}$ & $\%$ & $\begin{array}{l}\text { Milhōes } \\
\text { de } \\
\text { contos }\end{array}$ & $\%$ & $\begin{array}{l}\text { Milhōes } \\
\text { de } \\
\text { contos }\end{array}$ & $\%$ & $\begin{array}{c}\text { Milhơes } \\
\text { de } \\
\text { contos }\end{array}$ & $\%$ \\
\hline CEE & & & & & & & & \\
\hline Total dos «Nove» & 27,8 & 45,8 & 104,4 & 45,8 & 16,5 & 46,7 & 59,5 & 55,5 \\
\hline 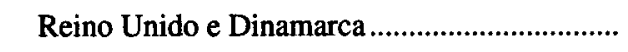 & 8,6 & 14,2 & 24,2 & 10,6 & 9,1 & 25,8 & 21,6 & 20,1 \\
\hline EFTA & 6,2 & 10,2 & 20,2 & 8,9 & 5,3 & 15,0 & 14,4 & 13,4 \\
\hline 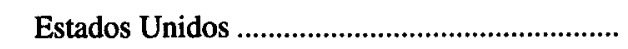 & 5,4 & 8,9 & 11,8 & 3,8 & 10,8 & 7,5 & 7,0 & \\
\hline Países europeus de economia planificada ........... & 0,5 & 0,8 & 5,9 & 2,6 & 0,2 & 0,6 & 3,3 & 3,1 \\
\hline 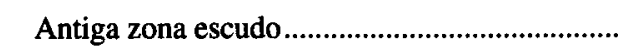 & 7,0 & 11,5 & 1,5 & 0,7 & 5,2 & 14,7 & 5,9 & 5,5 \\
\hline Outros & 13,8 & 22,7 & 69,0 & 30,3 & 4,3 & 12,2 & 16,6 & 15,5 \\
\hline Total & 60,7 & 100,0 & 227,9 & 100,0 & 35,3 & 100,0 & 107,2 & 100,0 \\
\hline
\end{tabular}

FONTE: Álvares e Fernandes ,1980: 35 
nomeadamente, conduziram a um incremento significativo das nossas relações comerciais com os países do Leste. Quanto às importações das nossas ex-colónias, elas diminuíram 93,5\%! Tinham desaparecido os especiais laços políticos e económicos que uniam a metrópole aos territórios ultramarinos e, simultaneamente, viam-se esses territórios a braços com graves problemas económicos, provocando grandes diminuições na oferta de produtos para comércio externo. A par dessa diminuição da capacidade de exportar, registava-se uma diminuição na capacidade de importar que explicará também, conjuntamente com as circunstâncias acima assinaladas, uma diminuição das nossas exportações de 62,5\% (sempre em termos relativos). Por fim, registou-se um aumento da importância do comércio com o resto do mundo, nomeadamente ao nível das importações, que aumentaram 33,4\% (em consequência da maior preponderância assumida pelos países produtores de petróleo e da emergência dos «novos países industrializados»), com um aumento de $27 \%$ nas exportações ${ }^{12}$.

Concluindo, terão sido traços característicos do período de tempo considerado a forte diminuição do relevo da antiga zona escudo nas nossas trocas comerciais, acompanhada de alguma intensificação nas trocas com o grupo residual do «resto do mundo», e o aumento da dependência de Portugal face à Europa (CEE e EFTA); a percentagem das exportações com destino europeu valiam em 1972 $61,7 \%$ e em 1978 68,9\% das exportações totais (não obstante, entre 1973 e 1977, a quota de mercado de Portugal na CEE e na EFTA decresceu 35\% (MACEDO e outro 1988), tendo-se mantido a tendência decrescente no mercado da EFTA); em 1978 quase $55 \%$ das nossas importações tinham origem europeia (a tendência é crescente; no fim das negociações para a entrada na CEE cerca de $60 \%$ das importações portuguesas provinham da CEE e da EFTA).

Falta referir qual tem sido a evolução da composição do comércio externo nas últimas décadas. Começemos pelas exportações. Com esse propósito, é útil analisar o Quadro V que, se bem que desactualizado, nos fornece valores que permitem apreciar rapidamente o evoluir da posição relativa que os produtos de base e os bens manufacturados têm vindo a ocupar no total das exportações. Assim, constata-se que a importância dos produtos de base tem vindo a declinar fortemente, enquanto que os produtos manufacturados ocupam um lugar cimeiro, passando de $20 \%$ das exportações em 1938 para 59,1\% em 1963. Na década de 60, contudo, é de salientar que a natureza das manufacturas exportadas pelo país é bastante diversa da natureza das manufacturas produzidas pelos países mais industrializados da Europa Ocidental, consistindo fundamentalmente em manufacturas de pouco valor acrescentado (v. g. produtos da indústria de madeira e cortiça). Começam, no entanto, a avultar na nossa balança comercial exportações não tradicionais para a época, como o vestuário e o calçado, os têxteis, os produtos das indústrias químicas, os produtos das indústrias de minerais não metálicos. 
Quanto às importações, na década de 60 distribuíam-se mais ou menos equitativamente pelos produtos de base e pelos produtos manufacturados.

$\mathrm{Na}$ época, as nossas relações com a EFTA decalcavam-se do modelo de trocas entre países de exportação primária e países industrializados, embora não tão perfeitamente como no caso das relações comerciais entre Portugal e a CEE dos «seis» (cfr. XAVIER, 1970: 49 ss); cerca de 70\% das nossas exportações eram constituídas por matéria-primas e bens alimentares, enquanto que os produtos manufacturados representavam à volta de $80 \%$ das nossas compras.

\section{QUADRO V}

Composição das exportações da Metrópole

(em percentagem)

\begin{tabular}{|c|r|r|r|r|r|r|r|}
\hline Classes de bens & 1938 & $1950-52$ & 1953 & $1955-57$ & 1959 & $1960-62$ & 1963 \\
\hline 1) Produtos de base & 80 & 64 & 57 & 55 & 50,4 & 49 & 40,9 \\
\hline $\begin{array}{r}\text { a) Produtos alimentares, bebi- } \\
\text { das e tabaco .................... }\end{array}$ & 51 & 28 & - & 29 & - & 28 & - \\
$\begin{array}{r}\text { b) Matérias primas, combustí- } \\
\text { veis e lubrificantes................ }\end{array}$ & 29 & 36 & - & 26 & - & 21 & - \\
\hline $\begin{array}{r}\text { 2) Bens manufacturados............. } \\
\text { Total .................................. }\end{array}$ & 100 & 100 & 100 & 100 & 100 & 100 & 100 \\
\hline
\end{tabular}

FONTE: Álvares e Fernandes 1980: 38

Mas a evolução referida supra está presente; se nos reportarmos ao Quadro III, vemos que a evolução das importações de têxteis e de vestuário da EFTA, com proveniência de Portugal, foi-nos excepcionalmente favorável entre 1959 e 1972, resultado da integração de Portugal na referida organização.

As importações de têxteis portugueses, em percentagem das importações de têxteis de todo o mundo, aumentam $1722 \%$ na Dinamarca e no Reino Unido (representando $4,29 \%$ das importações totais de têxteis) e $250 \%$ nos restantes 
países da EFTA (representando 3,22\% das importações totais de têxteis). Na CEE dos «seis» o aumento também é importante mas, não obstante, a quota de mercado portuguesa mantém-se diminuta: $0,38 \%$. A nossa quota-parte subiu igualmente no mercado americano.

A evolução na importação de vestuário é igualmente excepcional. Na Dinamarca e no Reino Unido a quota-parte portuguesa passou do nada em 1959 para 7,59\% em 1972. Nos restantes países da EFTA aumentou 3200\%. Desceu nos EUA e adquiriu algum significado na CEE, embora mínimo. São óbvios os efeitos de expansão das exportações. Por exemplo, em 1967 foram avaliados em 113 milhões de dólares, correspondendo a $55 \%$ das exportações portuguesas que foram beneficiadas pela preferência da EFTA (a média era de 28,5\%).

Pode-se pois afirmar, com a grande maioria dos autores (SILVA, 1989: 89), que a discriminação positiva a que as exportações portuguesas estiveram sujeitas durante os anos 60 , por parte da EFTA, se revestiu de um papel decisivo na transformação da estrutura económica do país.

O mesmo não se pode dizer da importância do Acordo com a CEE de 1972. À partida, o interesse de Portugal residiria na continuição de uma forte expansão das exportações onde lhe é reconhecida vantagem comparativa (v. g. têxteis, vestuário, calçado, produtos das indústrias de material eléctrico, produtos de papel e cortiça). Contudo, depararam-se sucessivas dificuldades, de onde o relativo insucesso na concretização plena desse objectivo. Logo no proceso de negociações do Acordo, não podia a CEE comportar-se do modo como se comportou a EFTA, concedendo preferências com semelhante cobertura de produtos e margens de preferências. Por duas razões. Em primeiro lugar, alguns dos produtos exportados competitivamente por Portugal concorriam com a produção de alguns países comunitários (especialmente a França e a Itália). Em segundo lugar, as concessões preferenciais a Portugal teriam de ser cuidadosamente articuladas com todo o edifício preferencial comunitário, de modo a não prejudicar certos países mediterrânicos ou africanos (contudo, essa articulação não impediu que Portugal readquirisse alguma competitividade em produtos como a cortiça, madeira, louças e calçado) ${ }^{13}$. Por tudo isto, não se produziram elevados efeitos da expansão de exportações. O máximo teria sido atingido em 1978, com um valor estimado de 250 milhões de dólares (SILVA, 1989: 111). O sector produtivo mais beneficiado foi o dos produtos das indústrias metalúrgicas (máquinas $\mathrm{e}$ material de transporte). Os sectores têxtil e do vestuário também beneficiaram de alguma expansão, embora muito relativa, se comparada com a da década anterior (v. Quadro III).

Simultaneamente (década de 70), o mercado da EFTA torna-se mais restritivo para Portugal. Em causa esteve a saída do Reino Unido e da Dinamarca, a negociação de um acordo de comércio livre entre esta organização e a CEE, que possibilitou a entrada preferencial de produção comunitária concorrente de Portugal, 
e o início da prática de autolimitação das exportações (no sector têxtil) para todos os mercados da EFTA (excepto a Suíça).

No que concerne às importações portuguesas, a discriminação positiva que Portugal conferiu aos produtos da EFTA produziu efeitos generalizados a praticamente todos os sectores produtivos, tendo sido mais intensos nos sectores dos têxteis e dos artigos diversos, e mais duradouros nos sectores dos produtos das indústrias metalúrgicas (metais) e dos artigos diversos. A CEE foi privilegiada nos sectores dos têxteis, produtos das indústrias metalúrgicas (metais) e dos artigos diversos, mas, quando muito, viu compensada a discriminação negativa a que tinha estado sujeita nos anos anteriores a 1972 no sector dos produtos das indústrias químias. Nem a EFTA (década de 70) nem a CEE extraíram vantagem no comércio de material de transporte e de máquinas industriais (para mais desenvolvimentos v. SILVA, 1989: 121 ss).

\section{IMPLICAÇÕES DA ADESÃO DE PORTUGAL ÀS COMUNIDADES EUROPEIAS NO REGIME ALFANDEGÁRIO APLICÁVEL AOS PAÍSES TERCEIROS}

Neste ponto do trabalho iremos, rapidamente, descrever o acquis comunitário adoptado por Portugal no quadro das relações comerciais externas. Como a plena entrada em vigor do regime alfandegário comunitário (tanto para o comércio intra-comunitário como para o comércio extra-comunitário) foi sujeita a adiamentos vários, forneceremos, em apêndice (fonte principal; MENDES e COELHO, 1990), um quadro esquemático do regime alfandegário aplicável por Portugal aos países terceiros durante o período transitório (grosso modo até $1993 \mathrm{e}$ 1996, respectivamente para produtos industriais e agrícolas).

O novo regime comercial a adoptar, na sua forma definitiva, por Portugal, face aos países terceiros, é caracterizado pelo seguinte:

a) entrada em vigor da Pauta Exterior Comum (PEC), que é o instrumento básico de protecção dos países comunitários face aos países terceiros. A substituição da pauta portuguesa pela PEC representa, como se viu, uma quebra nos valores médios da proteç̧ão nominal e da protecção efectiva portuguesa. Eliminação de outras barreiras pautais (v. g. sobretaxas) e não-pautais (v. g. atrasos no processamento administrativo dos Boletins de Registo de Importação);

b) entrada em vigor dos Acordos de Comércio Livre celebrados entre a Comunidade e os vários países da EFTA. Esses acordos criaram uma zona de comércio livre (supressão de direitos e de restrições quantitativas) para os produtos industriais (incluindo têxteis) e envolveram algumas concessões (limitadas) para os produtos agrícolas. Tendo em conta a anterior participação de Portugal na EFTA, não haverá alterações substanciais a assinalar;

c) participação nos acordos ACP (Convenções de Lomé). A Convenção de Lomé prevê a isenção de direitos e a não aplicação de restrições quantitativas (só 
cláusulas de salvaguarda), sem reciprocidade. Esta regra está sujeita a excepções, nomeadamente no que respeita a produtos abrangidos pela Política Agrícola Comum. Deste modo, Portugal deixará, por exemplo, de aplicar a cláusula da nação mais favorecida às suas ex-colónias, agora co-contratantes nas Convenções de Lomé;

d) entrada em vigor de todos os acordos (individuais) celebrados entre a Comunidade e um vasto conjunto de países mediterrânicos não comunitários (Argélia, Marrocos, Tunísia, Líbano, Egipto, Síria, Israel, Jugoslávia, Turquia, Malta e Chipre). Os produtos industriais destes países beneficiam, em termos gerais, de uma supressão de direitos e de restrições quantitativas. A importação preferencial de alguns produtos de certos países (Israel e Jugoslávia) está sujeita a limites máximos (adubos, artigos de viagem, têxteis, vidros, placas de alumínio). Está igualmente previsto que Israel, Turquia, Malta e Chipre concedam tratamento alfandegário preferencial aos países comunitários;

e) participação no SPG comunitário (Sistema de Preferências Generalizadas), como país concedente. Prevê-se a suspensão total de direitos com um alcance limitado (produtos sensíveis) ou não a contingentes e a limites máximos;

f) entrada em vigor de todos os acordos restritivos de comércio celebrados entre a Comunidade e terceiros países (v. g. restrições voluntárias à exportação, integrados ou não no Acordo Multifibras), que incidem, por exemplo, sobre a importação de têxteis, carne de cordeiro, mandioca, etc, etc. Harmonização das restrições quantitativas já aplicadas a países terceiros com aquelas aplicadas pela Comunidade (no que respeitava, por exemplo, aos países de comércio de Estado);

g) aplicação de todos os instrumentos de política comercial necessários à condução da Política Agrícola Comum (PAC) (v. g. preços indicativos e de intervenção, impostos alfandegários niveladores, restituições à exportação).

\section{IMPLICAÇÕES DA ADESÃO DE PORTUGAL ÀS COMUNIDADES EUROPEIAS NAS RELAÇÕES COMERCIAIS COM PAÍSES TERCEI- ROS}

\subsection{Alargamento e conflitos de interesses comerciais}

Antes de iniciarmos a análise de alguns dados estatísticos globais, convém esclarecer melhor (de acordo com o apêndice infra) algumas daquelas que seriam implicações forçosas da adesão, no que toca às relações comerciais com países terceiros, nomeadamente quanto aos EUA e aos países beneficiados pela «pirâmide» de preferências comunitária.

Os EUA puderam previsivelmente contar ser beneficiados pela adesão no que toca aos produtos industriais. Isto porque, como os autores apontam (PORTO, 1982; 195-203 e SOUSA e ALVES, 1985, passim), o nível de protecção para os 
produtos manufacturados teria forçosamente que diminuir, em termos gerais, em virtude do menor proteccionismo da PEC, a ser adoptado progressivamente a partir de 1986, e da eliminação das sobretaxas. Era portanto de contar com a produção de efeitos da criação de comércio nesse sector ${ }^{14}$. Por outro lado, haveria também que contar com algum desvio de comércio, em benefício da Espanha.

Mas os efeitos do desvio de comércio a sofrer pelos EUA em virtude do alargamento da CEE concentraram-se no sector agrícola; nas exportações de citrinos, discriminados negativamente face às exportações dos países mediterrânicos e, mais acentuadamente ainda, nas exportações de cereais.

Antes da adesão, os EUA dominavam completamente o mercado português dos cereais. Em 1984, 96,8\% dos cereais provinham desse país e, em 1985, 90,2\%. As quantidades importadas da CEE eram insignificantes: 3,3\% em 1984 e 4,4\% em 1985. A razão da concentração do comércio cerealífero em apenas um parceiro comercial prendia-se com a enorme diferença de preços existente entre os cereais americanos e os cereais comunitários.

Ora a entrada de Portugal na CEE obrigou o nosso país, por força da aplicação do princípio da preferência comunitária, a substituir importações de produtos agrícolas de países terceiros por importações dos mesmos produtos (ou sucedâneos) com origem comunitária, mais custosos. Estamos perante uma situação de desvio de comércio. Situação esta que, aliás, também prejudicou os PVD (países em vias de desenvolvimento). No caso específico dos cereais, o Tratado de Adesão previu que $15,5 \%$ das importações portuguesas fossem reservadas a fornecedores comunitários; o que significava uma elevada perda para os americanos, agravada ainda pelo facto de as importações portuguesas de cereais terem que diminuir sensivelmente, em virtude dos aumentos dos seus preços internos (preços a vigorar no âmbito da PAC). Essa perda, contabilizada em 90 milhões de dólares, foi acrescida de uma outra de 60 milhões de dólares, decorrente da perda de vendas de sementes oleaginosas.

Perdas essas que (como argumentou a Comissão das Comunidades) seriam parcialmente compensadas pelo aumento das exportações americanas de sucedâneos desses cereais (para a alimentação dos animais). Isto porque, tal como já tinha acontecido nas indústrias de fabrico de rações dos países onde a legislação comunitária já tinha sido introduzida, esses sucedâneos passaram a substituir os cereais (agora mais caros) no fabrico das rações. É o caso do corn gluten feed, do glúten de milho e da polpa de citrinos. A previsão das Comunidades, como veremos, confirmou-se.

Mas tal previsão não bastou para que os americanos se coibissem de traduzir os seus protestos em retaliações. Estas retaliações consistiram na fixação de impostos alfandegários de $200 \%$, penalizando a entrada de produtos comunitários num valor igual ao das exportações para os países ibéricos. De entre esses produtos (queijos, cognac, sumo de maçã, confeitaria, etc.), aquele que apresentou algum significado para Portugal foi o vinho branco de baixa qualidade. Após um período de negociações, as Comunidades e os EUA chegaram a um acordo, 
em 29.1.87 (renovado em 1990). Tal acordo previu a supressão dos $15 \%$ de quota preferencial formada por importações comunitárias (essa supressão beneficiou Portugal em cerca de 6 milhões de contos) e a redução unilateral de um conjunto de impostos alfandegários, por parte da CEE.

Pode-se adiantar que se confirmou que os EUA tinham alguma justifiicação ao retaliarem contra os acordos de adesão de Portugal e da Espanha. Estimou-se que as suas exportações para os dois países, em 1986-87, foram reduzidas em 763 e 1390 milhões de dólares, respectivamente, isto é, em valores superiores à estimativa de 1000 milhões de dólares, apresentada inicialmente pelos próprios EUA.

Passemos agora aos PVD. A adesão de Portugal (e nomeadamente da Espanha) à CEE afectou esses países, positiva e negativamente.

Por um lado, afectou-os positivamente ao fazer alargar a área geográfica em que as preferências alfandegárias comunitárias produzem efeitos. Nomeadamente no que respeita às suas exportações de produtos manufacturados, os PVD verão, em termos gerais, o nível de protecção de Portugal diminuir sensivelmente. Serão aí de esperar alguns efeitos de expansão de exportações.

YANNOPOULOS (1988: 43 ss.) considera mesmo não ser irrealista esperar que, terminado o período transitório, se tenha multiplicado por dois a percentagem das importações de manufacturas com origem nos PVD. Para chegar a esta conclusão, o autor comparou a percentagem de importações de manufacturas com origem nos PVD em Portugal (3,7\%) com a percentagem de importações de manufacturas com origem nos PVD em Itália (7,5\%) (dados de 1977), considerando estar em presença de dois países com semelhanças, do ponto de vista da estrutura dos custos e dos padrões de procura e de produção.

Em nossa opinião, tais efeitos de expansão de exportações não terão que ser de tal ordem de grandeza, devendo ter-se em conta vários factores: o padrão de especialização da indústria portuguesa (indústrias intensivas em trabalho pouco qualificado e mal remunerado) torna-a muito competitiva em muitos produtos concorrentes daqueles produzidos pelos PVD (vestuário, têxteis, material e máquinas eléctricas); a expansão de exportações dos PVD encontra-se frequentemente (e cada vez mais) controlada por acordos ou imposições unilaterais (comunitárias) restritivos do comércio; e, por último, se os PVD vêem, por um lado, as barreiras alfandegárias diminuírem (e os países não preferidos serem prejudicados), vêem, por outro lado, os outros Estados aderentes (Espanha e Grécia) beneficiar de condições ainda mais vantajosas. De onde poderá resultar desvio de comércio, nomeadamente afectando exportações de têxteis, vestuário e calçado (com prejuízo em especial para os países mediterrânicos). Além disso, a adesão (dos países ibéricos) afectou negativamente os PVD, de vários modos.

Em primeiro lugar, o alargamento da Comunidade reduziu o valor das preferências de que os PVD beneficiavam para a exportação de vários dos seus produtos para o mercado comunitário (pois passaram a contar com a concorrência de Portugal, da Espanha e da Grécia). A este propósito fala-se em «erosão» ou 
«diluição» de preferências. Esta «erosão» de preferências afecta nomeadamente o comércio de produtos agrícolas e prende-se com o comércio entre a CEE dos «nove» e os países terceiros. Dir-se-ia que, sendo assim, foje ao tema deste trabalho. Tal só não acontecerá se dessa erosão resultar uma maior exportação de produtos agrícolas (transformados) de Portugal para o mercado comunitário, e se essa maior exportação provocar, a montante e por parte de Portugal, uma maior importação de produtos agrícolas não transformados (de países terceiros).

Veja-se o caso do comércio entre Portugal e os países ACP. Uma característica marcante deste comércio é o fornecimento, por parte dos países $\mathrm{ACP}$, de matérias-primas para a indústria portuguesa, em vez de produtos elaborados, com maior valor acrescentado. A estrutura alfandegária portuguesa reflectia bem essa realidade, estimulando a exportação para Portugal de atum para conserva (em vez de atum já em conserva), de sisal (em vez de fio de sisal), de amendoim (em vez de óleo de amendoim), de palma (em vez de óleo de palma), de algodão, etc., etc. A importação desses produtos, necessários para a produção portuguesa, foi realmente favorecida pela adesão (outros produtos poderão também ser beneficiados, em consequência de uma diminuição na protecção: café e produtos do café, cacau e produtos do cacau, tabaco, certos vegetais e frutos). Em contrapartida, exportações de produtos como atum em conserva, fio de sisal, madeira e derivados, e produtos têxteis poderão vir a ser prejudicadas, pelo motivo acima aludido.

Em segundo lugar, a entrada em vigor, mesmo que progressiva, de todos os acordos preferenciais leva a que se gere algum desvio de comércio contra os PVD não beneficiários de preferências comunitárias (ou beneficiários de preferências de menor valia). Assim, por exemplo, países beneficiários do SPG comunitário serão discriminados negativamente face aos países mediterrânicos, e estes, possivelmente, serão discriminados face aos países ACP.

Em terceiro lugar, como se viu, a entrada na CEE obrigou Portugal, por força da aplicação do princípio da preferência comunitária, a substituir importações de produtos agrícolas de países terceiros por importações com origem comunitária. Tal provocará efeitos de desvio de comércio:

a) nas importações de cereais, em geral, e de gado. Os países prejudicados serão, entre outros, a Argentina, o Brasil e o Paraguai;

b) nas importações de carne de porco e de lacticínios;

c) em menor grau, nas importações de carne de vaca;

d) nas importações de tabaco, frutos (particularmente citrinos; v.g. laranjas e tomates de Marrocos), vegetais, sementes oleaginosas, vinhos, azeite (da Tunísia) e óleos vegetais. Aqui poderemos estar perante uma situação de desvio de comércio ou, em alternativa, de erosão de preferências acompanhada de possível criação de comércio. Os países mais prejudicados serão os países mediterâneos. $O$ país beneficiado será a Espanha;

e) nas importações de açúcar. Em princípio, a adesão de Portugal à CEE deveria acarretar uma alteração na origem das suas importações de açúcar, 
em prejuízo dos países da América Latina e em benefício dos países ACP. Contudo, a Acto de Adesão limitou a 70000 toneladas o açúcar (de cana) que Portugal pode importar desses países (em 1986), limite esse a diminuir progressivamente, substituindo-se gradualmente o açúcar de cana por açúcar de beterraba, produzido em excesso nas Comunidades.

\subsection{Adesão e Comércio Externo}

Vejamos agora como se comportou o comércio externo nos anos pós-adesão. A intenção é a de dar rapidamente conta das linhas gerais dessa evolução e apenas no que toca a alterações dos fluxos comerciais de primeira grandeza, possivelmente decorrentes da adesão de Portugal à CEE.

A tendência para o nosso comércio externo se concentrar mais e mais na CEE (ou, mais correctamente, no espaço europeu) afirmou-se renovadamente nos anos posteriores à adesão. Tal, aliás, seria de esperar, visto ter-se iniciado o desmantelamento das barreiras alfandegárias (e processado o desmantelamento das barreiras não alfandegárias), com incidência no comércio de produtos manifacturados e, especialmente, no comércio de produtos agrícolas.

Assim, de 1985 para 1986 as nossas importações com origem na CEE aumentaram (valores nominais) 65\%, de 1986 para $198747 \%$, de 1987 para $198836 \%$, e de 1988 para 1989 19\%. Neste último ano, as importações com origem comunitária representavam $68 \%$ das importações totais (acrescidas de $6,3 \%$ de importações da EFTA), dados recentes (e preliminares) do INE dizem-nos que, em 1991, as importações representaram cerca de $72 \%$ das importações totais. Quanto às exportações para as Comunidades, elas devem ter representado, em 1991, $75,8 \%$ do total. Se atendermos ao facto de que as mesmas representavam $58 \%$ do total em 1985, é fácil de apreciar, também aqui, qual tem sido a tendência dominante na evolução do comércio externo. MENDES e COELHO (1990) explicam este fenómeno pela existência de situações de reorientação e supressão do comércio ${ }^{15}$.

Em contrapartida, é evidente que se verificou uma forte diminuição das importações provenientes de países terceiros, com a possível excepção das importações provindas dos países mediterrânicos. $\mathrm{O}$ que poderá indiciar que as preferências concedidas pela $\mathrm{CEE}$ aos países mediterrânicos poderão já estar a fazer-se sentir (MENDES e COELHO, 1990). O fenómeno desta quebra de importações traduz, pelo seu lado, a ocorrência de efeitos significativos de desvio e de supressão de comércio.

Os EUA foram um dos países prejudicados por efeitos de desvio de comércio (que beneficiaram a Europa). As importações com proveniência norte-americana decresceram nominalmente $27 \%$ entre 1985 e 1987 (o que representa uma quebra em volume superior). A sua quota no mercado português decresceu fortemente, passando de $9,6 \%$ em 1985 para 4,4\% em 1989. Em 1991, ainda segundo dados 
preliminares do INE, os EUA passaram de sétimo para oitavo parceiro comercial de Portugal, trocando de posição com a Bélgica / Luxemburgo.

Esta evolução ficou a dever-se à quebra das cotações dos cereais e produtos oleaginosos e à diminuição do volume de importação. No caso específico das importações de cereais (e da importação do milho em particular, que decaiu, entre 1984 e 1989, 77\% em valor), há que acrescentar prejuízos decorrentes da aplicação dos mecanismos comunitários, em particular dos impostos niveladores, que aumentaram os preços de revenda. Uma das consequências de tal aumento (já referida) foi o facto de as indústrias utilizadoras de cereais tentarem encontrar matérias-primas sucedâneas. De 1985 para 1986 as importações de mandioca aumentam, em volume, 20\%. As quantidades de corn gluten feed, até 1985 insignificantes, aumentam 260\% em 1986; as de glúten de milho 124\% (sempre em volume). Estes produtos são importados dos EUA, o que pode ter minorado as perdas desse país.

Por outro lado, as exportações para os EUA registaram uma quebra de $7 \%$ (em valor) entre 1985 e 1986, registando, nos anos subsequentes, tendência para alguma recuperação. Essa quebra pode, pelo menos em parte, ser explicada pela perda das preferências dadas pelos EUA ao abrigo do SPG. Só em parte, visto que o SPG americano não cobria mais de $30 \%$ das nossas exportações para aquele país, não abrangendo, por exemplo, a totalidade do sector têxtil (que, aliás, passou a estar abrangido pelo Gentleman"s Agreement existente entre a CEE e os EUA, vendo, por esse facto, desaparecer a possibilidade de the serem impostas restrições quantitativas para a exportação nesse país). Outros factores explicativos têm a ver com possíveis efeitos de retaliações e, em particular, e como já se disse, com efeitos de supressão de comércio devidos à oferta inelástica.

\title{
APÊNDICE: PERÍODO TRANSITÓRIO
}

\author{
E. F. T. A.
}

\section{EXPORTAÇÕES:}

Produtos industriais (excluindo têxteis):

Acordos de Comércio Livre implicam:

- introdução de impostos;

- aumento de impostos; art. 368 T.A. (Tratado de Adesão); as medidas de transição e as adaptações eventuais foram objecto de protocolos concluídos com os países co-contratantes. V. também art. 366 T.A.

Produtos têxteis:

- eliminação dos contingentes têxteis (são produtos industriais). Países EFTA mantêm apenas a possibilidade de invocar cláusulas de salva- 
guarda. Existe contudo troca regular de informação estatística relativa às importações e exportações referentes ao sector têxtil (mecanismo de cooperação administrativa).

- continuação da prática de autolimitação nas nossas exportações para a Áustria, a Finlândia, a Noruega e a Suécia.

Produtos agrícolas e agrícolas transformados:

- fim do Acordo Portugal / EFTA que considerava alguns produtos dos caps. 1 a 24 como industriais (conservas de peixe, tomate e vinhos);

- introdução de impostos alfandegários.

\section{IMPORTAÇÕES:}

Produtos industriais (excluindo têxteis):

- eliminação dos impostos residuais para a EFTA (que não tivessem sido ainda eliminados em 1.1.85) (tendo em conta ACL CEE-EFTA e acordos CECA-EFTA). Os impostos de que se parte para o alinhamento são os impostos constantes da Convenção de Estocolmo, a lista de isenções constante do Anexo XVIII (no caso em que a Convenção indique que há impostos) e a lista do Protocolo 15. A duração do alinhamento é de 7 anos.

- reintrodução dos impostos para a EFTA para os produtos cobertos pela Convenção de Estocolmo e não cobertos pelos ACL CEE-EFTA.

- aumento de impostos (tendo em conta diferenças entre a Convenção de Estocolmo e os ACL CEE-EFTA).

- Protocolo Automóvel (n. 23) (restrições quantitativas por dois anos: art. 364 T.A.).

Produtos agrícolas e agrícolas transformados:

- protocolos de adaptação para a aplicação dos ACL. V. arts. 243 e 360 ;

- aplicação dos ACL;

- alargamento dos contingentes limitado pelas restrições quantitativas (anexos 21, 26 e 29).

\section{PAÍSES DESENVOLVIDOS (OCDE):}

\section{EXPORTAÇÕES:}

Produtos industriais (excluindo têxteis):

- perda das preferências concedidas no quadro dos SPG dos EUA, do Canadá, do Japão, da Nova Zelândia e da Austrália.

- acordo de autolimitação para as exportações de aço com os EUA. 
Produtos têxteis:

- Gentleman's Agreement Têxtil com os EUA (inaplicabilidade de restrições quantitativas).

Produtos agrícolas e agrícolas transformados:

- possíveis efeitos de retaliações nos conflitos comerciais com os EUA (v.g. o caso dos cereais).

\section{IMPORTAÇÕES:}

Produtos industriais:

- alinhamento da pauta portuguesa pela PEC (excepto nos casos em que a diferença entre as incidências de uma e da outra seja inferior a 15\%; nesse caso o alinhamento verificou-se em 1.1.87). Os impostos de que se parte para o alinhamento são os impostos da pauta mínima (aplicáveis à generalidade dos países GATT), acrescentados daqueles constantes da lista de isenções constante do Anexo XVIII (no caso em que a Pauta indique que há impostos) e da lista do Protocolo 15. calendário do alinhamento: 1. 3. 86: 10\%; 1. 1. 87: 10\%; 88: 15\%; 90: 10\%; 91: 10\%; 92: 15\%; 93: 15;

- o alinhamento pela pauta unificada CECA far-se-á ao mesmo ritmo (art. 197 T.A.);

- acordadas derrogações temporárias à aplicação do regime GATT no que respeita à manutenção de restrições quantitativas (progressivamente diminuídas). Até 31. 12. 92. Anexo XXX (art. 364 / 3. T.A.);

- introdução do regime de aperfeiçoamento activo;

Produtos agrícolas e agrícolas transformados;

- desmantelamento dos monopólios de importação;

- produtos do regime de transição clássica;

- adopção da PEC em 1.3.86 para os casos em que a Pauta portuguesa fosse inferior;

- nos casos em que a Pauta portuguesa fosse superior e para os produtos constantes do anexo $\mathrm{XX}$ o alinhamento processa-se através de 8 reduções (12.5\%) excepto oleoginosas e azeite (10 anos).

- restrições quantitativas (contingentes anuais sujeitos a aumentos anuais) até 31.12.92. Art. 245 T.A. Anexo XXI;

- produtos do regime de transição por etapas;

- aplicação da PEC a partir de 1.3.86, excepto para os produtos do anexo XXV (até ao início da 2." etapa; 1.1.91);

- restrições quantitativas até 31.12.95. Art. 280 T.A. Anexo XXVI; 


\section{PAÍ́SES ACP}

\section{IMPORTAÇÕES:}

Produtos industriais (excluindo têxteis):

- eliminação progressiva (7 anos) por Portugal de todos os impostos para os produtos (industriais) considerados pela Comunidade como sensíveis. Os produtos sensíveis são cerca de 100 no sector industrial (correspondem aos produtos sensíveis face à Comunidade acrescidos dos produtos especificamente sensíveis face aos países ACP) (art. 189 T.A.);

- introdução do regime de aperfeiçoamento activo.

Produtos têxteis:

- a Comunidade pode estabelecer com estes países convénios de cooperação administrativa;

- introdução do regime de aperfeiçoamento activo.

Produtos agrícolas e agrícolas transformados:

- introdução das preferências ao longo de 7 anos (protocolo de adaptação);

- rum e bananas têm protocolos específicos;

- no que respeita ao azeite, sementes, frutos oleaginosos e produtos derivados, Portugal pôde adiar o início da aplicação progressiva do regime preferencial até 1991 . O período transitório tem a duração de cinco anos e termina em 1.1.96. Art. 295 T.A.

\section{PAÍSES MEDITERRÂNICOS:}

\section{IMPORTAÇÕES}

Produtos industriais (excluindo têxteis):

- introdução de taxas preferenciais (produtos sensíveis) ao longo de 7 anos (art. 189 T.A.) (acompanhadas de restrições quantitativas);

- introdução do regime de aperfeiçoamento activo.

Produtos têxteis:

- a maior parte dos países mediterrânicos tem limitado voluntariamente as suas exportações para a Comunidade. Está previsto o mecanismo da cláusula de salvaguarda;

- introdução do regime de aperfeiçoamento activo. 
Produtos agrícolas e agrícolas transformados:

- introdução dos acordos preferenciais (reduções pautais com limites máximos) ao longo de 7 anos (protocolo de adaptação) (lista de produtos sensíveis e de restrições quantitativas, com a mesma duração);

- no que respeita ao azeite, sementes, frutos oleaginosos e produtos derivados, Portugal pôde adiar o início da aplicação progressiva do regime preferencial até 1991. O período transitório tem a duração de cinco anos e termina em 1.1.96, Art. 295 T.A.

\section{OUTROS PAÍSES EM VIAS DE DESENVOLVIMENTO:}

\section{IMPORTAÇÕES:}

Produtos industriais (excluindo têxteis):

- introdução do SPG comunitário, aplicação progressiva (7 anos) por parte de Portugal do SPG para todos os produtos considerados como sensíveis. Todos os produtos considerados como sensíveis provenientes da Comunidade têm também de ser considerados como sensíveis provenientes de países terceiros (princ. da pref $f^{a}$ comunitária) (os produtos considerados como sensíveis provenientes da Comunidade são aqueles sujeitos a impostos residuais (durante o período transitório de 7 anos). Vêm incluídos no Anexo XXXI; art. 365/1 T.A. e Anexo II Tratado CEE);

- adopção não progressiva do SPG para todos os outros produtos;

- introdução do regime do aperfeiçoamento activo.

Produtos têxteis:

- adesão ao AMF; no quadro do AMF existem acordos bilaterais de autolimitação acompanhados da concessão de preferências «generalizadas» (suspensões pautais e suspensões pautais acompanhadas de limites máximos comunitários, e eventualmente de contingentes anuais para os Estados-membros importadores);

- introdução do regime do aperfeiçoamento activo.

Produtos agrícolas e agrícolas transformados:

- introdução do SPG agrícola (isenções e reduções pautais com contingentes);

- para a generalidade dos produtos submetidos à transição clássica o período transitório previsto é de 10 anos. $\mathrm{O}$ calendário das reduções comporta onze $(10 \times 9,1 \%+9 \%)$, a primeira das quais em 1.3.86. Art. 365 T.A.;

- no que respeita ao azeite, sementes, frutos oleaginosos e produtos derivados, Portugal pôde adiar o início da aplicação progressiva do regime preferencial até 1991 . O período transitório tem a duração de cinco anos e termina em 1.1.96. Art. 295 T.A. 


\section{NOTAS}

1. Parece, no entanto, que a tributação alfandegária não teve como propósito primordial proteger efectivamente a indústria nacional. Pois os impostos alfandegários protegem determinada produção local quando oneram produção concorrente provinda do exterior, mas desprotegem-na quando oneram matérias-primas e bens de produção que, entendidos como inputs não primários do respectivo processo produtivo, farão repercutir esse ónus tributário sobre o produto final, nessa medida desprotegendo-o face à concorrência externa. Assim, como afirma PORTO (1982: 50), «com a medição da protecção efectiva tem-se em conta não só a tributação que recai sobre os bens finais, mas também a que recai sobre a importação de bens utilizados na sua produção». Ora a proteç̧ão efectiva, pese embora o aparente maior relevo dos impostos alfandegários, pode ter declinado ao longo do período em causa (MACEDO e outros, 1988: quadro $n .^{\circ}$ 6). Não que tal se devesse a uma preocupação governamental no sentido de afectar os recursos por via dos mecanismos de mercado. Talvez a resposta se encontre antes no facto de que a tributação alfandegária da época, nomeadamente no que respeita à Pauta (específica) de 1959, se encontrava fortemente condicionada à prossecução de objectivos reditícios. Esses objectivos seriam melhor alcançados através de um levantamento possível nas restrições quantitativas e da imposição de um nível geral de impostos (não muito elevado), que poderá, eventualmente, ter prejudicado sectores produtivos mais dependentes de bens intermediários (latu sensu) importados.

2. Foram as seguintes as reduções alfandegárias aprovadas: bens importados pela metrópole, com origem nos territórios ultramarinos, pagariam apenas $30 \%$ do imposto alfandegário mínimo, ou estariam isentos (casos do chá, do gado, das madeiras, da fruta e do peixe); bens importados pelos territórios ultramarinos, com origem na metrópole, pagariam $50 \%$ do imposto alfandegário a vigorar nesses territórios.

3. Comparando o regime do anexo $\mathrm{G}$ e o regime comum da Convenção, fácil é retirar conclusões acerca da posição relativamente favorecida de Portugal; assim, segundo o regime comum, o desarmamento alfandegário processar-se-ia segundo o calendário e com a cadência seguintes (os valores apresentam a percentagem do imposto em vigor antes da adesão): Julho de 1960:80\%; Janeiro de 1963: 70\%; Julho de 1964: 60\%; Janeiro de 1965: 50\%; Janeiro de 1966: 40\%; Janeiro de 1967: 30\%; Janeiro de 1968: 20\%; Janeiro de 1969: 10\%. Em 1970 o desarmamento alfandegário estaria completo, pelo lado dos co-contratantes de Portugal na EFTA. Quanto a Portugal, o levantamento dos seus impostos seria bastante mais suave (os valores representam a percentagem do imposto em vigor antes da adesão): Janeiro de 1960: 80\%; Janeiro de 1965: 70\%; Janeiro de 1967: 60\%; Janeiro de 1970: 50\%. O processo estaria completo com a abolição do imposto residual (50\% do original) passados dez anos, em 1980.

4. Enquanto que o regime comum previa que a última redução se efectuasse em Julho de 1977, Portugal só atingiria a fase do imposto nulo em 1980 e 1985, dependendo das listas de produtos. Inseriu-se também uma cláusula de proteç̧ão das indústrias nascentes (mas não se previu a protecção específica de indústrias orientadas para a substituição de importações). No que respeita à manutenção de contingentes, ambas as partes se socorreram desse instrumento de limitação de importações; Portugal manteve contingentes para a importação de automóveis e de aço (CECA) e, em contrapartida, os países das CEE impuseram contingentes para a importação de produtos a que eram sensíveis: têxteis, artigos de vestuário, polpa de papel, concentrado de tomate e minerais. Exactamente produtos que se revelaram como sendo das principais exportações portuguesas.

5. Os factores externos a que se fez referência foram determinantes; veja-se como se reflectiu a subida de preço dos produtos petrolíferos, da maioria dos bens intermediários primá- 
rios e dos produtos alimentares no indíce de valor médio das importações totais, o qual (na base 1972=100) acusou uma subida de 108 pontos em 1973, e uma outra para 161 pontos em 1974, praticamente de $50 \%$. No mesmo período de tempo, o indíce de valor médio das exportações aumentava muito menos significativamente (para 110 e 148, respectivamente).

6. Que passamos a enumerar:

- aumentos (para o dobro) nos impostos específicos em mais de $25 \%$ dos itens tributados alfandegariamente, procurando-se contrariar a tendência para a sua desvalorização (uma maior utilização deste instrumento de política comercial estar-nos-ia vedada pelo acordado no âmbito da EFTA, da CEE e do Tokyo Round). Inevitavelmente tais aumentos repercutiram-se, de forma assinalável, nos valores das taxas médias de protecção nominal e efectiva (cfr. MACEDO e outros 1988, que compara valores de 1974 e 1977);

— imposição de sobretaxas de $20 \%$ para os bens intermediários ( $30 \%$ das importações) e de $30 \%$ para os bens de consumo ( $8 \%$ das importações). As sobretaxas, impostas com declarado carácter de provisoriedade, tinham que ser renovadas anualmente. Os valores das sobretaxas e o leque de produtos que abrangiam foram variando de ano para ano, atingindo um valor máximo de 60\% e um mínimo de 10\% (1984), com tendência decrescente (excluindo 1983) (MACEDO e outros, 1988; 71-72; PORTO, 1986a);

- obrigatoriedade de se efectuarem depósitos prévios, no montante de $50 \%$ do valor das importações, seis meses antes dessas importações. Os depósitos não eram remunerados. As importações em questão representaram aproximadamente $10 \%$ das importações de produtos industriais. Estes depósitos foram abolidos em 1977 (PORTO, 1986a);

— utilização dos Boletins de Registo de Importação (BRI) com finalidade não estatística; a sua concessão, não automática (contrariamente ao que acontecia desde os anos 40), serviu como instrumento de controlo das importações e, na prática, reduziu o volume de importações de um extenso número de produtos. Provocou também uma elevação dos preços internos e uma maior incerteza nas transacções;

- fixação de contingentes, nomeadamente no que respeitou à importação de bens de consumo com elevada elasticidade-rendimento (v.g. vestuário, electrodomésticos, automóveis). Eram estabelecidos anualmente e foram-se tornando cada vez mais restritivos, já que eram definidos em valores monetários, sem ter em conta a perda de poder de compra da moeda portuguesa. Em 1978 2,8\% das importações estavam sujeitas a contingentes, reduzindo-se essa percentagem para $1,3 \%$ em 1979 ;

— desvalorização do escudo, a partir da segunda metade de 1976. A desvalorização da moeda nacional produziu dois tipos de efeitos, de sinal contrário; atenuação dos efeitos da inflação interna sobre a competitividade das exportações e deterioração dos termos de troca, isto é, diminuição da capacidade de importar. Para ÁLVARES e FERNANDES (1980; 24-25) a desvalorização teve, globalmente, um efeito positivo (estimulante) na economia portuguesa, sustentando o ritmo de actividade de certos sectores e não se repercutindo fortemente no défice da balança de pagamentos correntes (como aconteceria se Portugal exportasse exclusivamente produtos de procura inelástica). Outros autores (DONGES e SCHATZ, 1989: 271) consideram que a desvalorização mais do que compensou o diferencial de inflação entre Portugal e os seus parceiros comerciais, implicando uma depreciação real do escudo, e mantendo em actividade sectores produtivos em que Portugal já tinha perdido vantagem comparativa, ou em que previsivelmente iria perder;

— existência de restrições cambais;

— concessão de subsídios à indústria.

7. O acordado no âmbito da EFTA, da CEE e das negociações do GATT impediria também uma maior utilização da pauta como instrumento de política comercial. Por esse facto, e também pelo facto de as barreiras não alfandegárias assumirem crescente importância relativa como instrumentos de controlo do comércio externo, as médias de protecção vão perdendo 
grande parte do seu valor como indicadores da liberalização do comércio externo (no período pós-74).

8. Atenta a inexistência de barreiras naturais, seria então de esperar um significativo aumento dos fluxos comerciais entre Portugal e Espanha. Não houve, no entanto, grande liberalização do comércio entre os dois vizinhos, pois mantiveram-se altas barreiras não alfandegárias. O que fez com que os efeitos do livre comércio entre Portugal e a Espanha, potencialmente dos mais significativos (juntamente com aqueles decorrentes da liberalização comercial dos produtos agrícolas), se viessem a manifestar apenas aquando da adesão dos dois países às Comunidades.

9. Mas é de notar que esse aumento de proteç̧ão se fazia praticamente apenas face a países terceiros à EFTA e às Comunidades, mesmo esses beneficiados com redução resultante de compromissos internacionais (com excepção para as indústrias nascentes).

10. É evidente que os dois fenómenos estão relacionados, pois, tratando-se de mercado com padrões de procura similares, não era possível aos exportadores portugueses, por limitações de oferta, aproveitar as oportunidades lançadas pela integração na EFTA sem que, pelo menos parcialmente, tal provocasse desvio de fluxos comerciais (export trade diversion)

11. Veja-se, por exemplo, que as exportações de têxteis passaram a estar afectadas pela imposição de limites máximos e os concentrados de tomate foram transferidos para a categoria dos produtos agrícolas.

12. Outros dados, que corroboram os anteriores, podem ser vistos no Quadro III, para o período de 1972 a 1977.

13. A estes factores acresceram outros, aqui indicados por ordem cronológica: a recessão económica; as perturbações ocorridas na actividade económica em 1974-75; a negociação de restrições voluntárias à exportação, em 1978 e em 1979-1981 (que, na opinião de SLLVA, 1989: 108), anulara possíveis efeitos da expansão de exportações, decorrentes do Acordo de 72, que pudesse vir a verificar-se a partir de 1979.

14. Os EUA exportam tradicionalmente para Portugal os seguintes produtos semi-acabados e acabados: chapas de ferro macio e aço, veículos automóveis e de carga destinados à indústria de montagem, tractores, carros empilhadores, máquinas e aparelhos, partes e peças separadas para aviōes, etc.

15. Entende-se reorientação de comércio como sendo um favorecimento das trocas com os outros Estados membros da união aduaneira que não se relaciona com os preços relativos, mas que é induzido pelo «espírito de união»; entende-se por supressão de comércio a eliminação de importações e de exportações entre Estados membros e não-membros resultante, quer da instalação de novas unidades produtivas na união, quer da inelasticidade da oferta em determinados sectores, relativamente a deslocações da curva da procura induzidas por aumentos da procura interna nos sectores a jusante ou a montante.

\section{BIBLIOGRAFIA}

ÁlVARES, Pedro, e FERNANDES, Carlos Roma, 1980, Portugal e o Mercado Comum, Lisboa, Editorial Pórtico.

ÁLVARES, Pedro, 1986, Portugal na CEE, Lisboa Publ. Europa-América.

ÁLVARES, Pedro, 1990, A Europa e o Mundo, Lisboa, Publ. Europa-América. 
CONSTÂNCIO, Maria José, 1987, «A indústria portuguesa face à adesão à CEE», Alfândega, n. ${ }^{\circ}$, p. 17-23.

DONGES, Juergen B, e SCHATZ, Klaus-Werner, 1989, «The Iberian Countries in the EEC-risks and changes for their manufacturing industries», in Yannopoulos, G. N. (org.), Integration and the Iberian Economies, Londres e Reading, Macmillan e The Graduate School of european and International Studies (Universidade de Reading), p. 255-306.

FARIA, Carlos Roma, 1980, «As implicações da adesão de Portugal às Comunidades Europeias nas trocas comerciais com os países terceiros», in $2 .{ }^{a}$ Conferência Internacional sobre Economia Portuguesa, Lisboa, Fundação Calouste Gulbenkian/The German Marshall Fund of the United -States, vol. $2 .^{\circ}$, p. 989-1011.

GRANJA, Carlos, 1989, «Dossier Têxteis 1992», Alfândega, n. ${ }^{\circ} 13$ / 14, p. 48-61.

MACEDO, Jorge Braga de, CORADO, Cristina e PORTO, Manuel, 1988, The timing and sequencing of trade liberalization policies: Portugal 1948-1986, Working Paper n. ${ }^{\circ} 114$, Universidade Nova de Lisboa, Faculdade de Economia.

McQUEEN, Matthew, e READ, Robert, 1986, «The effects of Portugal's accession to the European Community on the exports of the ACP countries», Estudos de Economia, vol. 6, n. ${ }^{\circ}$, p. 369-383.

MENDES, A. J. Marques, e COELHO, Lina Paula, 1990, Comércio externo e adesão à CEE; condicionantes e potencialidades de Portugal e da Região Centro, Coimbra, Comissão de Coordenação da Região Centro.

MINISTÉRIO DOS NEGÓCIOS ESTRANGEIROS, 1988, Portugal nas Comunidades Europeias; terceiro ano.

MINISTÉRIO DOS NEGÓCIOS ESTRANGEIROS, 1990, Portugal nas Comunidades Europeias; quinto ano.

OLIVEIRA, Dias de, 1987, «Comércio externo», Alfândega, n. ${ }^{\circ}$ 5, p. 8-11.

POMFRET, R., 1989, «The impact of the EEC enlargement on non-member Mediterranean countries'exports to the EEC», Economic Journal, vol. 91. Setembro, p. 726-730.

PORTO, Manuel C. L., 1982, Estrutura e Política Alfandegárias; o caso português, Coimbra, Separada do Boletim de Ciências Económicas da Faculdade de Direito de Coimbra.

PORTO, Manuel C. L., 1986, «Preferências Aduaneiras», Enciclopédia Polis, vol. IV. Lisboa, Verbo p. 1456-1468.

PORTO, Manuel C. L., 1986a, «Proteccionismo», Enciclopédia Polis, vol. IV, Lisboa, Verbo, p. 1666-1682.

PROENÇA, Luisa 1989, «Evolução da estrutura do comércio externo português face à adesão à CEE», Boletim do Conselho Nacional do Plano, n. ${ }^{\circ} 19,145-165$.

RIBEIRO, J. F. Castro, 1986, «A adesão de Portugal e Espanha às Comunidades e o seu impacto nas relações comerciais Portugal / CEE / países preferenciais», A Indústria do Norte, $6 .^{\mathrm{a}}$ série, $\mathrm{n} .^{\circ}$ p. 17-29.

ROCHA, Nuno da, 1985, «Implicações aduaneiras da adesão de Portugal às Comunidades», Alfândega, $\mathrm{n} .{ }^{\circ}$ 0, p. 5-9.

ROCHA, Nuno da, 1987, «Alfândega; 1 ano de viragem», Alfândega, n. ${ }^{\circ}$ 5, p. 3-7.

SOUSA, Fernando Freire de, e ÁLVARES, Isabel, 1985, A adesão de Portugal à CEE; o imoacto do desarmamento aduaneiro português, Cadernos BPA. 
XAVIER, Alberto Pinheiro, 1970, Portugal e a Integração Económica Europeia, Coimbra, Livraria Almedina,

YANNOPOULOS, G, N., 1988, Customs Unions and Trade Conflicts; the enlargement of the European Community, Londres e Nova Iorque, Routledge. 